\title{
稲葉陽子 学位論文審査要旨
}

$\begin{array}{cccc}\text { 主査 } & \text { 井 } & \text { 藤 } & \text { 雄 } \\ \text { 副主查 } & \text { 汐 } & \text { 田 } \text { 剛 } & \text { 史 } \\ \text { 同 } & \text { 寺 } & \text { 直 } & \text { 樹 }\end{array}$

\section{主論文}

Peroxisome proliferator-activated receptor $-\gamma$ ligand reduced tumor necrosis factor $\alpha$-induced interleukin-8 production and growth in endometriotic stromal cells （子宮内膜症間質細胞においてPPAR $\gamma$ リガンドはTNF $\alpha$ 誘導性のIL-8産生と細胞増殖を抑制す る)

（著者：大浜陽子、原田省、岩部富夫、谷口文紀、竹中泰子、寺川直樹）

平成19年6月 Fertility and Sterility 掲載予定 


\section{学 位 論 文 要 旨}

\section{Peroxisome proliferator-activated receptor- $\gamma$ I igand reduced tumor necrosis factor $\alpha$-induced interleukin-8 production and growth in endometriotic stromal cells}

（子宮内膜症間質細胞においてPPAR $\gamma$ リガンドはTNF $\alpha$ 誘導性のIL-8産生と細胞増殖を抑 制する）

子宮内膜症は生殖年齢女性に発症し、疼痛と不妊を惹き起こす疾患である。本症の病因 はいまだ明らかではないが、腹腔内局所の炎症が重要な役割を果たすと考えられている。 これまでに、本症患者腹水中にはInterleukin-6(IL-6)、IL-8、Tumor necrosis factor $\alpha$ （TNF $\alpha$ ) などのサイトカインが高濃度存在すること、TNF $\alpha$ は転写因子NF-kBを介して子宮内 膜症細胞からのIL-8産生を誘導し、IL-8は内膜症細胞の増殖を促進することを報告してき た。Peroxisome proliferator-activated receptors（PPARs）は核内受容体スーパーファ

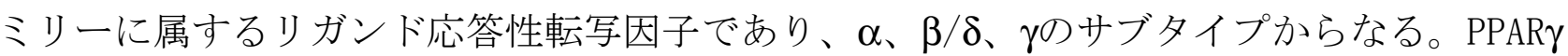
のリガンドであるピオグリタゾンはインスリン抵抗性改善薬として使用されている。本研 究では、抗炎症作用を有するピオグリタゾンが子宮内膜症間質細胞におけるTNF $\alpha$ のL-8産 生誘導と細胞増殖に及ぼす影響について検討した。

\section{方 法}

患者の同意のもと、手術時に採取した卵巣チョコレート囊胞壁から分離培養した子宮内 膜症間質細胞を対象とした。PPAR

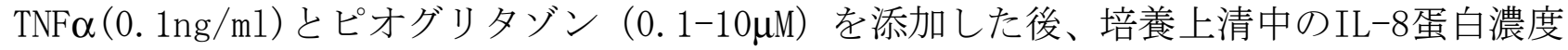
をELISAで測定し、内膜症間質細胞の増殖能はBrdUで検討した。リン酸化IkBの蛋白発現を Western blot法で、核内p65蛋白濃度をELISAで測定することにより NF-kBの活性化を評価し た。

\section{結 果}

RT-PCR 免疫染色により、子宮内膜症間質細胞にPPAR $\gamma$ の遺伝子および蛋白発現を証明し た。PPAR $\gamma$ 蛋白の発現は核内で優位であった。TNF $\alpha$ 添加で培養上清中のIL-8蛋白濃度は増 加し、ピオグリタゾンの添加でIL-8蛋白濃度は減少した。TNF $\alpha$ はrdUの取り込みを有意 
に促進したが、ピオグリタゾンの添加でこの取り込みは抑制された。ピオグリタゾンの添 加はリン酸化IkBの発現に影響を与えなかったが、核内p65蛋白濃度を有意に低下させた。

\section{考 察 と 結 論}

子宮内膜症治療薬として現在最も汎用されているGnRHアゴニストは、血中エストロゲン 濃度を低下させることで本症の増殖・進展を抑制する。しかしながら治療後の再発率は高 く、副作用として骨密度の減少をきたすことから、新たな治療薬の開発が期待されている。

核内受容体の一つであるPPAR $\gamma$ は種々の組織に発現し、子宮内膜細胞においてもその発現 が確認されている。ラット子宮内膜症モデルを用いた検討では、PPAR $\gamma$ リガンドの投与は血 管新生を抑制して内膜症病変の退縮を促し、内膜症の進展を抑制することが報告されてい る。PPAR $\gamma$ リガンドの抗炎症作用は、NF-kB活性を抑えることでサイトカイン産生を阻止す ることが単球やマクロファージにおいて示されている。

一方、PPARyのシグナル伝達機序は多様であり、いまだその詳細は明らかではない。NF-kB はp50/p60蛋白の二量体からなり、細胞内では抑制蛋白であるIkBが結合した状態で核内一 の移行をブロックされている。刺激が細胞内に伝達されるとIkBはリン酸化されてNF-kBか ら遊離し、活性型NF-kBは核内に移行して標的遺伝子の転写を促進する。

本研究では子宮内膜症間質細胞におけるPPAR

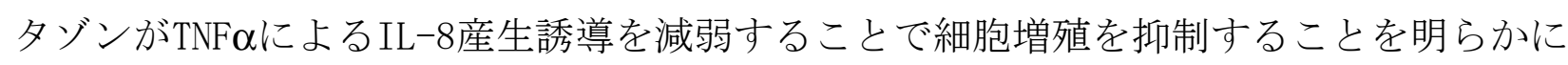
した。ピオグリタン゙ンはリン酸化IkB蛋白発現に影響を与えなかったが、核内のp65蛋白濃 度を有意に低下させたことより、 $\mathrm{NF}-\mathrm{kB}$ の核内移行を阻害する作用が考えられた。以上の成 績より、PPARyリガンドが子宮内膜症治療薬となる可能性が示唆された。 